\title{
Breeding of early ripening potato varieties under the conditions of the Kabardino-Balkarian foothill zone
}

\author{
Aniuar Abazov ${ }^{1}$, Khaset Abidov ${ }^{1}$ Sultan Basiev², and Khusein Nazranov",* \\ ${ }^{1}$ Institute of agriculture - the branch of the RAS (Russian Academy of Sciences) Kabardino-Balkarian \\ Research Center, Kirov str., 224, 360004 Nalchik, Russia, \\ ${ }^{2}$ Federal State Budgetary Educational Institution of Higher Education Gorsky State Agrarian \\ University, Kirov str., 37, 362040 Vladikavkaz \\ ${ }^{3}$ Kabardino-Balkarian State Agrarian University named after V.M. Kokov, Lenin str., 1V, 360004 \\ Nalchik, Russia
}

\begin{abstract}
Evolution and thousands of years of artificial selection have contributed to the formation of the widest variety of cultivated potatoes. Thanks to this, more than 4 thousand varieties of potatoes have been created in the world today. All of them are known to differ not only in habit, but also in the level of yield, ripening period, resistance degree to numerous diseases and pests, plasticity to certain climatic and soil conditions. The results of research and evaluation of 4 thousand hybrids of the 1st tuber generation (single-tuberous plants) of joint breeding of the Institute of Agriculture ISKh KBNTs RAN and FSBSI (Federal state budgetary scientific institution) "Federal Research Center (FRC) of Potato name after A.G. Lorkh" that passed the full scheme of breeding tests, 9 promising cross-breed populations with economically useful traits were identified: consistently high yield and resistance to a complex of viral, bacterial and fungal diseases. The selected cross-breeds are distinguished by early and medium early ripening periods with a growing season of 55-70 days and a maximum yield of 38.6-66.2 ton/ha, depending on the prevailing weather conditions during the growing season of potato plants in 2019-2020. The genotypes obtained are involved in the implementation of the federal scientific and technical program for the development of potato growing for 2017-2030. The main goal of the program is to create new varieties of early ripeness group of potatoes. The co-executors of this program are a number of research institutes of the Russian Federation, including the Institute of Agriculture ISKh KBNTs RAN. [1] As a result of many years of investigation, the promising cross-breed 2652-15 that emerged from breeding of the Malinovka variety with the backcross $93.20-12$ under the name Zamir was transferred in 2020 for the State test of the Russian Federation in the North Caucasian region. Medium early variety for table use and mashed potatoes processing. Potential yield is 49.5 ton/ha. Tubers of an attractive rounded oval shape with shallow eyes weighing 85.5-108.4 $\mathrm{g}$ with a yellow color of the tuber and creamy flesh. The tubers are resistant to mechanical damage during combine harvesting, storability is good. Medium resistant to late
\end{abstract}

* Corresponding author: nazranov777@mail.ru 
blight in tops and highly resistant to tubers. Relatively resistant to rhizoctonia and common scab, banded and wrinkled mosaic of leaves.

\section{Introduction}

Early "young" potatoes are distinguished by excellent taste and culinary qualities. At the same time, the tubers contain small amounts of vitamins $\mathrm{B}_{1}$ (aneurin), PP (niacin), $\mathrm{B}_{2}$ (riboflavin), A (carotene), as well as mineral salts of calcium, iron, potassium, sulfur and other substances that are extremely necessary for the normal functioning of the human body. $[2,3]$ However, the nutritional value of potatoes is significantly reduced during long-term storage in the summer and autumn period. So, if in new harvested tubers the content of vitamin "C" is $20-25 \mathrm{mg}$ per $100 \mathrm{~g}$ of raw weight, after 2-3 months it decreases to $12-13 \mathrm{mg}$, and after 5-6 months to 7-9 $\mathrm{mg}$ [3]. Therefore, the creation of early ripening varieties of new generation potatoes is one of the most important areas of breeding, especially for the southern regions of Russia. Among more than 40 economically useful traits inherent in the new potato variety, resistance to the most common pathogens is one of the most significant. In particular, late blight remains one of the most harmful pathogens, which is very problematic to prevent $[4,5]$. At the same time, most potato varieties created in the 90 s of the XX century do not withstand the infectious load due to the emergence of new strains and phytopathogens, which leads to a significant shortage of harvest $[6,7,8]$. In this regard, modern breeding is experiencing great difficulties in the process of new genetic sources and effective donors in the creation of genotypes with complex resistance to the most harmful fungal diseases (late blight, rhizoctonia, alternaria) and severe forms of viruses (X, Y), combining early ripeness with high productivity and consumer qualities of tubers. The investigation purpose is to conduct breeding trials and selection of a new potato genotypes group and to identify the most promising early and mid-early varieties to ensure efficient production under the conditions of the Southern Federal District of Russia.

\section{Materials and methods}

To determine and clarify the potential of the isolated genotypes, a field experiment was laid with a randomized placement of plots in 4 several-fold repetition on the experimental fields of the laboratory for potato breeding and seed production of the Institute of Agriculture ISKh KBNTs RAN in the Zolsky district of Kabardino-Balkaria.

Field nursery-gardens for cross-breeds testing were located at an altitude of 1,500 m above sea level under the conditions of leached black soil for medium loamy granulometric composition with the following agrochemical characteristics: humus - 6.1-6.8\%; the soil solution reaction - $(\mathrm{KCl})$ - 5.3-6.6; $(\mathrm{pH})$ - 6.4-6.7\%. $\mathrm{P}_{2} \mathrm{O}_{5}$ content - 3.3-4.7; $\mathrm{K}_{2} \mathrm{O}-35-44$ $\mathrm{mg} / 100 \mathrm{~g}$. The predecessor is grain crops, bean cultures.

The meteorological conditions during the years of the investigation were distinguished in 2019 by the abundance of precipitation and their even distribution during the growing season. In 2020 , on the contrary, it was characterized by high soil and air temperatures. During the period of budding and flowering, a lack of moisture was marked (second half of June, early July), which negatively affected the growth and development, first of all, of varieties of early ripening. 


\section{Research Results}

The breeding process of highly productive new generation potato varieties included the solution of the following problems [9]:

- the initial material investigation for the effective selection of parental forms with high combinational ability;

- analysis of cross-breed offspring with the selection of recombinants with high productivity, early ripeness, good consumer qualities, resistant to the most common diseases;

- testing promising genotypes under various soil and climatic conditions in order to determine their adaptive potential.

Rational use of available genetic resources focused on achieving complex resistance to various pathogens of high productivity, early ripeness and quality of tubers made it possible to select ecologically adaptive genotypes in a relatively short time. In particular, when conducting trial digging in 2019, in 65 days after planting to clarify the early ripeness of genotypes, experimental data were obtained on yield, harvesting of grocery-ware tubers, average weight of grocery-ware tuber, starch content, dry matter, resistance to viral and fungal diseases. (Table 1)

Table 1. Yield structure of promising cross-breeds of breeding site (2019-2020).

\begin{tabular}{|c|c|c|c|c|c|c|c|c|c|c|}
\hline \multirow[t]{3}{*}{$\begin{array}{c}\text { Breeding } \\
\text { number }\end{array}$} & \multirow[t]{3}{*}{ Origin } & \multirow{2}{*}{\multicolumn{2}{|c|}{ Yield (t/ha) }} & \multirow{3}{*}{$\begin{array}{c}\text { Groce } \\
\text { ry- } \\
\text { ware } \\
\text { tubers } \\
, \%\end{array}$} & \multirow{3}{*}{$\begin{array}{l}\text { Ave } \\
\text { rage } \\
\text { wei } \\
\text { ght } \\
\text { of } 1 \\
\text { tube } \\
\text { r, g }\end{array}$} & \multirow{3}{*}{$\begin{array}{c}\text { Star } \\
\text { ch } \\
\text { cont } \\
\text { ent, } \\
\%\end{array}$} & \multirow{3}{*}{$\begin{array}{c}\text { Dry } \\
\text { matt } \\
\text { er } \\
\text { cont } \\
\text { ent, } \\
\%\end{array}$} & \multicolumn{3}{|c|}{$\begin{array}{c}\text { Disease } \\
\text { resistance, grade }\end{array}$} \\
\hline & & & & & & & & \multirow{2}{*}{$\begin{array}{r}\text { Vir } \\
\text { al }\end{array}$} & \multirow{2}{*}{$\begin{array}{c}\text { Late } \\
\text { blig } \\
\text { ht }\end{array}$} & \multirow{2}{*}{$\begin{array}{c}\text { Alte } \\
\text { rnar } \\
\text { ia } \\
\text { dise } \\
\text { ase }\end{array}$} \\
\hline & & 2019 & 2020 & & & & & & & \\
\hline St-d & Udacha & 38.6 & 11.1 & 63.6 & 63.0 & 14.0 & 19.7 & 5 & 7 & 7 \\
\hline $1755-55$ & $\begin{array}{l}\text { Santana } \mathrm{x} \\
\text { Gala }\end{array}$ & 45.4 & 15.1 & 85.5 & 64.4 & 14.3 & 20.1 & 7 & 7 & 5 \\
\hline $2588-122$ & $\begin{array}{l}\text { Udacha } \mathrm{x} \\
88.16 / 20\end{array}$ & 39.2 & 12.8 & 77.5 & 70.7 & 19.4 & 25.1 & 7 & 7 & 9 \\
\hline St-d & Nevskiy & 42.5 & 14.1 & 68.4 & 63.2 & 16.8 & 22.5 & 5 & 5 & 9 \\
\hline $4704-15$ & - & 49.1 & 20.6 & 82.6 & 90.3 & 13.5 & 19.3 & 5 & 7 & 7 \\
\hline $1871-2$ & $\begin{array}{l}\text { Krasavitsa } \\
\text { x Tiras }\end{array}$ & 42.9 & 15.2 & 84.8 & 77.4 & 17.7 & 23.4 & 5 & 9 & 7 \\
\hline $2652-15$ & $\begin{array}{l}\text { Malinovka } \\
\text { x 93.20-12 }\end{array}$ & 49.5 & 29.3 & 82.3 & 71.1 & 15.7 & 21.5 & 7 & 5 & 5 \\
\hline $2520-152$ & $\begin{array}{l}\text { Udacha } \mathrm{x} \\
88.16 / 20\end{array}$ & 52.6 & 30.4 & 81.4 & 87.4 & 17.2 & 22.9 & 7 & 7 & 9 \\
\hline $1869-1$ & $\begin{array}{l}\text { Tabor } \mathrm{x} \\
\text { Tiras } \\
\end{array}$ & 50.7 & 12.4 & 74.4 & 50.7 & 13.3 & 19.0 & 7 & 9 & 7 \\
\hline $2591-1$ & $\begin{array}{l}\text { Lira } x \\
\text { Ausonia } \\
\end{array}$ & 66.2 & 14.8 & 67.2 & 59.9 & 21.0 & 26.8 & 7 & 7 & 5 \\
\hline $2721-172$ & $\begin{array}{l}\text { Kondor X } \\
97.4-4\end{array}$ & 53.2 & 25.7 & 99.1 & 90.8 & 14.9 & 20.7 & 5 & 7 & 9 \\
\hline
\end{tabular}

It should be marked that during the first trial digging (2020), there were no grocery-ware tubers in the samples.

During the 2019 harvesting period there was a high potato grocery-ware tubers in five promising cross-breeds: $1755-55$ (Santana $\times$ Gala) $-85.5 \%$; 4704-15 - 90.3\%; 1871-2 $($ Krasavitsa $\times$ Tiras $)-84.8 \%$; 2652-15 (Malinovka $\times 93.20-12)-82.3 \%$; 2520-152 (Udacha $\times 88.16 / 20-81 \%)$.

The largest average weight of 1 tuber was recorded in four investigated genotypes: 4704$15-90.3 \mathrm{~g} ; 2520-152-87.4 \mathrm{~g} ; 1871-2-77.4 \mathrm{~g}$ and $2652-15-71.1 \mathrm{~g}$. 
Increased starchiness of tubers was found in breeding cross-breeds: 2588-122 - 19.4\%; $2520-152-17 \% ; 2591-1-21.0 \% ; 1871-2-17.7 \%$, significantly exceeds the standard, dry matter $-25.1 \% ; 22.9 \% ; 26.8 \%$ and $23.4 \%$, respectively.

Meteorological conditions in 2019 had the most significant influence on the productivity of cross-breeds, since this year the maximum potato yield was formed. At the same time, among the promising cross-breeds, the highest yield level was established in early ripeness cross-breeds: $1755-55$ - 45.4 ton/ha; 2652-15 - 49.5 ton/ha; 2520-152 - 52.6 ton/ha and midearly - 1871-2 - 42.9 ton/ha; 4704-15 - 49.1 ton/ha, i.e. the excess relative to the standard was $6.8 ; 10.6 ; 10.9 ; 14.0 ; 12.0$ ton/ha.

The yield level of promising potato varieties in 2020 is formed significantly lower due to a lack of moisture, early death of tops and a shift in phenophases during the growing season of plants. Moreover, the negative reaction of genotypes of early and mid-early ripening periods was marked to the greater ripeness. It should be noted that under such extreme weather conditions, the selected cross-breeds turned out to be, nevertheless, the best in terms of productivity and grocery-ware tuber indicators that indirectly indicates a high resistance to bio- and abiostressors of the environment, heat and drought hardness. Among the best indices in terms of productivity there were the same cross-breeds as in 2019:2652-15;2520152 ; 4704-15; 1755-55. Their yield level was 15.1-30.4 ton/ha.

Table 2. Results of table quality evaluation and culinary type for promising cross-breeds (2020).

\begin{tabular}{|c|c|c|c|c|c|c|c|c|c|}
\hline \multirow{2}{*}{$\begin{array}{c}\text { Breeding } \\
\text { number of } \\
\text { the cross- } \\
\text { breed }\end{array}$} & \multirow[t]{2}{*}{ Origin } & \multicolumn{8}{|c|}{ Indices of tuber table qualities, grade } \\
\hline & & $\begin{array}{c}\text { Shell } \\
\text { comp } \\
\text { leten } \\
\text { ess }\end{array}$ & $\begin{array}{c}\text { Fles } \\
\mathrm{h} \\
\text { den } \\
\text { sity }\end{array}$ & $\begin{array}{l}\text { Friabi } \\
\text { lity of } \\
\text { mealy }\end{array}$ & $\begin{array}{l}\text { Wat } \\
\text { ery }\end{array}$ & $\begin{array}{c}\text { Flesh } \\
\text { darke } \\
\text { ning } \\
\text { after } \\
\text { cooki } \\
\text { ng }\end{array}$ & $\begin{array}{c}\text { Sme } \\
11\end{array}$ & $\begin{array}{c}\text { Tast } \\
\mathrm{e}\end{array}$ & $\begin{array}{l}\text { Culin } \\
\text { ary } \\
\text { type }\end{array}$ \\
\hline $2520-152$ & $\begin{array}{l}\text { Udacha } x \\
88.16 / 20\end{array}$ & 7 & 5 & 5 & 7 & 9 & 7 & 7 & VS \\
\hline $2652-15$ & $\begin{array}{l}\text { Malinovka x } \\
93.20-12\end{array}$ & 7 & 7 & 7 & 7 & 7 & 7 & 7 & $\mathrm{C}$ \\
\hline $2588-122$ & $\begin{array}{l}\text { Udacha } \mathrm{x} \\
88.16 / 20\end{array}$ & 7 & 5 & 7 & 7 & 7 & 9 & 7 & $\mathrm{C}$ \\
\hline $2591-1$ & Lira $\mathrm{x}$ Ausonia & 5 & 3 & 5 & 5 & 3 & 5 & 5 & V. \\
\hline $2721-172$ & $\begin{array}{l}97.4-4 \mathrm{x} \\
\text { Kondor } \\
\end{array}$ & 3 & 7 & 1 & 3 & 9 & 7 & 5 & A. \\
\hline $1755-55$ & Santana x Gala & 3 & 7 & 3 & 5 & 9 & 7 & 7 & $\mathrm{AV}$ \\
\hline $1871-2$ & $\begin{array}{l}\text { Krasavitsa } \mathrm{x} \\
\text { Tiras }\end{array}$ & 5 & 5 & 5 & 5 & 9 & 7 & 9 & VS \\
\hline $1869-1$ & Tabor $\mathrm{x}$ Tiras & 1 & 7 & 1 & 3 & 9 & 9 & 9 & A. \\
\hline $4704-15$ & - & 3 & 5 & 3 & 3 & 7 & 7 & 7 & A. \\
\hline
\end{tabular}

High indices of taste and culinary properties of tubers were appeared in two promising cross-breeds: 2520-152 (Udacha x 88.16/20) and 2652-15 (Malinovka x 93.20-12), the second of which was submitted for the State Variety Test in 2020 (Table 2). In addition, promising cross-breeds are distinguished: 1755-55 (Santana x Gala), 1871-2 (Krasavitsa x Tiras) and genotype 4704-15, which after the "rehabilitation" will also be prepared for submission to the State Variety Test of the Russian Federation. 


\section{Conclusion}

As a result of many years of investigation, the distinguished cross-breed 2652-15 that obtained as a result of introgressive breeding of the Malinovka variety with the backcross 93.20-12 under the name Zamir was transferred in 2020 for the State test of the Russian Federation in the North Caucasian region. The Zamir variety, in terms of ripening time, is one of the most demanded in the mid-early group. Suitable for table use and treatment into mashed potatoes. Potential yield is $49.5 \mathrm{ton} / \mathrm{ha}$. A tuber of an attractive rounded oval shape with shallow eyes weighing 85.5-108.4 g has a yellow tuber color and creamy flesh. The tasting assessment of boiled tubers is good (6.0 to 7.0 grades), moderately boiled, resistant to darkening of the flesh in raw type and after boiling. The tubers are resistant to mechanical damage during combine harvesting, good storability is the main feature $(90.0-95 \%)$.

According to the conclusion of the All-Russian point for testing potato cultivars for resistance to cancer and nematode at the Federal State Budgetary Scientific Institution of the Federal Research Center of potatoes named after A.G. Lorkh, it is resistant to the Dahlem cancer pathotype and potato golden cyst nematode (pathotype $\mathrm{R}_{0} 1$ ). It is characterized by an average level of late blight resistance in tops and height in tubers. Relatively resistant to rhizoctonia and common scab, banded and wrinkled mosaic of leaves.

\section{References}

1. A. Kh. Abazov, H. K. Abidov, A. I. Sarbasheva, G. Kh. Abidova, R. A. Gazheva, Izvestia KBNTs RAN, 6(97) (2020)

2. K. Z. Budin, A. I. Kuznetsov, I. M. Fomin, N.V. Shaburov, Production of early potatoes in the Non-Black Earth Region (1984)

3. E. E. Brown, Early Potatoes (1983)

4. S. D. Kiru, L.I. Kostina, E.V. Rogozin, I. A. Chalaya, Global potato genetic resources and their use in modern breeding trends, 44 (2012)

5. A.V. Filipov, Supplement to the j. Plant Protection and Quarantine, 5(27) (2012)

6. S. D. Kiru, Scientific support and innovative development of potato growing, 49 (2008)

7. E. A. Simakov, N. P. Sklyarova, I. M. Yashina, Guidelines for the technology of the potato breeding process (2006)

8. E. I. Koshkin, Crop Pathophysiology (2016)

9. A. N. Berezkin, A. M. Malko, E. L. Minin, V. N. Lapochkin, M. Yu. Cherednichenko, Regulatory framework for breeding and seed production (2019) 